\title{
PENGGUNAAN INFORMASI KEUANGAN UNTUK MEMPREDIKSI KEUNTUNGAN INVESTASI BAGI INVESTOR PADA PERUSAHAAN FOOD AND BEVERAGES DI BEI
}

\author{
Lita Pebriana, Vidya Vitta Adhivinna \\ Universitas PGRI Yogyakarta, Jl. PGRI I No.117 Sonosewu, Yogyakarta. \\ email: litapebriana23@gmail.com
}

\begin{abstract}
Abstrak
Investor perlu mengetahui kondisi perusahaan sebelum melakukan investasi. Informasi keuangan perusahaan dapat dijadikan sebagai indikator penilaian terhadap suatu perusahaan. Tujuan penelitian ini adalah menguji apakah pertumbuhan laba, perputaran persediaan, Return On Equity (ROE) dan Return On Asset (ROA), merupakan prediktor keuntungan investasi (laba per lembar saham) di masa mendatang. Variabel penelitian terdiri dari Pertumbuhan Laba (X1), Perputaran Persediaan (X2), ROE (X3), ROA (X4) dan Laba Per Lembar Saham (Y).

Populasi penelitian ini adalah data laporan keuangan perusahaan manufaktur sub sektor makanan dan minuman yang terdaftar di Bursa Efek Indonesia pada periode 2011 - 2015. Penelitian ini menggunakan teknik regresi linear berganda dan metode analisis data purposive sampling.

Hasil dari penelitian ini bahwa pertumbuhan laba dan perputaran persediaan berpengaruh negatif dan tidak signifikan terhadap laba per lembar saham (EPS), Return On Equity (ROE) berpengaruh negatif dan signifikan, sedangkan Return On Asset (ROA) berpengaruh positif dan signifikan. Nilai adjusted $R$ square sebesar 0,774. Hal ini menunjukkan bahwa variabel independen yang diteliti mampu menjelaskan $77,4 \%$ variabel dependen, sedangkan sisanya dipengaruhi oleh variabel diluar model.
\end{abstract}

Kata Kunci: Pertumbuhan Laba, Perputaran Persediaan, ROE, ROA dan EPS.

\begin{abstract}
Investor need to know the company condition before they do an investment there. The purpose of this research is examine what profit growth, inventory ratio, return on equity (ROE) dan return on asset (ROA) are predictor of investment profit (earning per share) in the future. Research variabels of this research are profit growth (X1), inventory ratio (X2), ROE (X3), ROA (X4) and earning per share $(Y)$.

The population of this research is financial statement data of manufactur company sub sectored food and beverages listed in BEI on 2011-2015. This research uses multiple linear regression and purposive sampling.

The result of this research that profit growth and inventory ratio have negative influence and not significant on earning per share (EPS), return on equity (ROE) have negative influence and significant and return on asset (ROA) have positive influence and significant. Value of adjusted $R$ square is 0,774. It show that independents variable in this research can explain $77,4 \%$ on dependent variable, while the residue is influenced by variable in the outside of model.
\end{abstract}

Keyword: Profit growth, inventory ratio, ROE, ROA and EPS. 


\section{Pendahuluan}

Berkembangnya kegiatan dibidang ekonomi dan bidang bisnis menyebabkan perusahaan-perusahaan giat mencari sumber pembiayaan yang dapat menyediakan dana dalam jumlah besar untuk keperluan usaha dan keperluan lainnya yaitu dengan menerbitkan kepemilikan sekuritas atau saham dan menjualnya pada masyarakat umum melalui pasar modal. Hal ini dibuktikan dengan semakin maraknya perusahaan yang melakukan penawaran atas kepemilikan sekuritas di Bursa Efek Indonesia. Sebelum melakukan investasi, investor perlu menganalisis sebuah perusahaan, investor dapat menilai kondisi perusahaan menggunakan laporan keuangan perusahaan. Di setiap peristiwa, informasi yang terkandung dalam sebuah laporan keuangan akan digunakan oleh para investor untuk membantunya membuat ekspektasi tentang laba dan dividen di masa mendatang.

Menurut Amaliah, dkk (2016) laporan keuangan perusahaan cenderung fluktuatif dari tahun ke tahun dengan tingkat partumbuhan yang berbeda tiap tahunya, sedangkan informasi keuangan memiliki peran yang sangat penting dalam penentuan investasi atau pengambilan keputusan investasi bagi investor dan calon investor. Besarnya pembagian dividen sangat dipengaruhi besarnya laba per saham atau Earnings Per Share (EPS). Laba per saham (EPS) sangat penting karena merupakan pendapatan bagi perusahaan untuk investor dan menjadi tolak ukur investor untuk menanamkan modalnya pada perusahaan. Tingginya jumlah EPS akan meningkatkan kepercayaan investor untuk menambah investasinya yang mana sangat dibutuhkan oleh pihak perusahaan. EPS yang tinggi merupakan tolak ukur kemampuan perusahaan memperoleh pendapatan bersih (Diaz dan Jufrizen, 2014).

Menurut Harahap (2005:297) Rasio keuangan adalah angka yang diperoleh dari hasil perbandingan dari satu pos laporan keuangan dengan pos lainya yang mempunyai hubungan yang relevan dan signifikan, artinya rasio keuangan sangat penting dalam melakukan analisis terhadap kondisi keuangan perusahaan. Indikator yang digunakan untuk melihat kemampuan perusahaan memperoleh profitabilitas yang dapat menghasilkan laba per lembar saham bagi investor dan calon investor ditunjukan dari beberapa rasio keuangan antara lain pertumbuhan laba, perputaran persediaan, Return On Equity (ROE), dan Return On Asset (ROA). Rasio ini merupakan rasio yang dapat mengetahui keadaan perusahaan yang banyak mengalami peningkatan profitabilitas karena tingkat keuntungan itu benar-benar profit atau tidak, maka dibutuhkan rasio yang sesuai dengan kebutuhan perusahaan.

\section{Kajian Teori}

\section{Laporan Keuangan}

Menurut Widyawati, dkk (2016) Laporan keuangan berupa neraca, laporan laba rugi dan laporan arus kas yang merupakan gambaran dari kinerja suatu perusahaan, yang berisi perkembangan perusahaan tersebut. Dari situlah investor mendapatkan indikator sebagai bahan pertimbangan untuk berinvestasi, juga guna meminimalkan resiko dalam berinvestasi. Dari sudut pandang investor, peramalan masa depan adalah inti dari analisis keuangan yang sebenarnya. Sementara itu, dari sudut pandang manajemen, analisis laporan keuangan berguna untuk membantu mengantisipasi kondisi masa depan, yang lebih penting adalah sebagai titik awal untuk merencanakan tindakan-tindakan yang akan memperbaiki kinerja di masa depan (Brigham dan Houston, 2010: 133).

\section{Saham}

Sedangkan menurut Sjahrial (2012:19) saham adalah surat berharga yang dikeluarkan oleh sebuah perusahaan yang berbentuk perseroan terbatas atau yang disebut dengan emiten. Saham menyatakan bahwa pemilik saham tersebut juga pemilik sebagian dari sebagian perusahaan itu.Dengan demikian bila seorang investor membeli saham, maka 
dia juga menjadi pemilik atau pemegang saham perusahaan.

\section{Analisis Rasio Keuangan}

Rasio keuangan merupakan alat analisis keuangan yang paling sering digunakan. Rasio keuangan menghubungkan berbagai perkiraan yang terdapat pada laporan keuangan sehingga kondisi keuangan dan hasil operasi suatu perusahaan dapat diinterpretasikan. Analisis rasio keuangan terutama bertujuan untuk mendapat gambaran tentang baik buruknya keadaan keuangan suatu perusahaan pada saat dianalisis. Berdasarkan hasil analisis tersebut manajemen akan memperoleh suatu informasi tentang kekuatan dan kelemahan perusahaan. Informasi tersebut dapat membantu manajer dalam memahami apa yang perlu dilakukan perusahan selain itu manajer dapat membuat keputusan-keputusan penting di masa yang akan datang.

\section{Pertumbuhan Laba}

Laba merupakan angka penting dalam laporan keuangan, karena laba merupakan dasar dalam perhitungan pajak, pedoman dalam menentukan kebijakan investasi dan pengambilan keputusan, dasar dalam peramalan laba maupun kejadian ekonomi perusahaan lainnya di masa yang akan datang, dasar dalam perhitungan dan penilaian efisiensi dalam menjalankan perusahaan, serta sebagai dasar dalam penilaian prestasi atau kinerja perusahaan (Harahap, 2005:263).

\section{Perputaran Persediaan}

Persediaan barang sebagai elemen yang utama dari modal kerja merupakan aktiva yang selalu dalam keadaan berputar, di mana secara terus menerus mengalami perubahan. Menurut Bambang (2001) kesalahan dalam penetapan besarnya investasi dalam inventory akan menekan keuntungan perusahaan. Adanya investasi dalam inventory yang terlalu besar dibandingkan dengan kebutuhan akan memperbesar beban bunga, memperbesar biaya penyimpanan dan pemeliharaan di gudang, memperbesar kemungkinan kerugian karena kerusakan, turunnya kualitas, sehingga semuanya ini akan memperkecil keuntungan perusahan. Demikian sebaliknya, adanya investasi yang terlalu kecil dalam inventory juga akan mempunyai efek yang menekan keuntungan perusahaan.

\section{Return On Equity (ROE)}

Menurut Sartono (2010) Return On Equity mengukur kemampuan perusahaan memperoleh laba yang tersedia bagi pemegang saham perusahaan. Rasio ini juga dipengaruhi oleh besar-kecilnya utang perusahaan, apabila proporsi utang makin besar maka rasio ini juga akan makin besar. Return On Equity (ROE) secara eksplisit menghitung kemampuan perusahaan menghasilkan suatu laba bagi pemegang saham biasa.

\section{Return On Asset (ROA)}

Menurut Darmadji dan Fakhrudin (2012: 158) ROA adalah rasio yang sering digunakan untuk mengukur kemampuan perusahaan untuk menghasilkan laba atas asset yang dimiliki perusahaan. ROA yang besar akan menarik minat para investor untuk menanamkan dananya kedalam perusahaan. ROA yang besar akan menunjukkan kinerja perusahaan dalam menghasilkan laba semakin baik. ROA digunakan untuk mengukur efektivitas perusahaan dalam menghasilkan keuntungan dengan memanfaatkan aktiva yang dimilikinya.

\section{Laba Per Lembar Saham (Earning Per Share)}

Earning Per Share (EPS) atau laba per lembar saham adalah tingkat keuntungan bersih untuk tiap lembar sahamnya yang mampu diraih perusahaan pada saat menjalankan operasinya. Syamsuddin (2009) mengatakan bahwa pada umumnya manajemen perusahaan, pemegang saham biasa dan calon pemegang saham sangat tertarik akan Earning Per Share (EPS), karena hal ini 
menggambarkan jumlah rupiah yang diperoleh untuk setiap lembar saham biasa. Para calon pemegang saham tertarik dengan EPS yang besar, karena hal ini merupakan salah satu indikator keberhasilan suatu perusahaan.

\section{Metode Penelitian}

\section{Obyek Penelitian}

Penelitian ini menggunakan data sekunder, data sekunder merupakan sumber data penelitian yang diperoleh peneliti secara tidak langsung melalui media perantara (diperoleh dan dicatat oleh pihak lain) berupa laporan keuangan setelah audit yang di publikasikan di Bursa Efek Indonesia periode 2011-2015.

\section{Jenis dan Sumber Data}

Jenis data penelitian ini menggunakan jenis data kuantitatif yaitu data yang diukur dengan suatu skala numerik yang dihasilkan dari data yang diolah. Data kuantitatif dalam penelitian ini berasal dari laporan keuangan setelah audit dari 14 perusahaan sub sektor makanan dan minuman (food and beveragees) yang dipublikasikan di Bursa Efek Indonesia tahun 2011 sampai dengan tahun 2015.

\section{Populasi dan Teknik Pengambilan Sampel}

Populasi dalam penelitian ini adalah Perusahaan Manufaktur Sektor Industri Barang Konsumsi Sub Sektor Makanan dan Minuman (food and beverages) yang terdaftar di Bursa Efek Indonesia periode 2011-2015. Jumlah populasi dalam penelitian ini sebanyak 14 perusahaan. Pemilihan sampel dari penelitian ini menggunakan metode purposive sampling.

\section{Teknik Pengumpulan Data}

Teknik pengumpulan data dalam penelitian ini diperoleh dengan cara dokumentasi, dimana penulis mencari data langsung dari laporan keuangan yang ada pada Perusahaan Manufaktur Sektor Industri Barang Konsumsi Sub Sektor Makanan dan Minuman (food and beverages) yang terdaftar di Bursa Efek Indonesia periode 2011-2015, kemudian menganalisis variabel dependen terhadap variabel independen.

\section{Uji Hipotesis dan Analisis Data}

Metode analisis data adalah suatu teknik atau prosedur untuk menguji hipotesis penelitian. Metode yang digunakan dalam penelitian ini adalah uji statistik deskriptif, uji asumsi klasik dan pengujian hipotesis.

\section{a. Uji Statistik Deskriptif}

Statistik deskriptif digunakan untuk membantu menggambarkan keadaan (fakta) yang sebenarnya dari suatu penelitian, yaitu untuk memberikan gambaran secara umum mengenai karakter variabel dalam penelitian ini.

\section{b. Uji Asumsi Klasik}

Pengujian hipotesa dilakukan dengan menggunakan uji regresi linier berganda. Agar memperoleh model regresi yang terbaik, dibutuhkan sifat tidak bias linier terbaik (BLUE atau Best Linier Unbiased Estimator) dari penaksir atau prediktor. Serangkaian uji dapat dilakukan agar persamaan regresi yang terbentuk dapat memenuhi persyaratan BLUE ini, yaitu uji normalitas, uji multikolinieritas, uji autokorelasi, dan uji heteroskedastisitas.

\section{c. Uji Hipotesis}

Untuk menganalisis data, penelitian ini menggunakan teknik analisis regresi linear berganda. Analisis Regresi linier berganda pada dasarnya merupakan perluasan dari regresi linier sederhana. Analisis regresi linier berganda bertujuan untuk menerangkan pengaruh penggunaan informasi keuangan terhadap keuntungan investasi yang berupa laba per lembar saham. Jadi analisis regresi ganda akan dilakukan bila jumlah variabel 
independennya minimal 2.

$$
\mathrm{Y}=\alpha+\beta 1 \mathrm{X} 1+\beta 2 \mathrm{X} 2+\beta 3 \mathrm{X3}+\beta 4 \mathrm{X} 4+e
$$

Keterangan:

$\mathrm{Y}=$ Earning Per Share (EPS).

$\mathrm{X} 1$ = Pertumbuhan Laba.

$\mathrm{X} 2=$ Perputaran Persediaan.

$\mathrm{X} 3=$ Return On equity (ROE).

$\mathrm{X} 4$ = Return On Asset (ROA).

$\alpha=$ Koefisien konstanta.

$\beta 1,2, \beta 3, \beta 4=$ Koefisien regresi.

$e=$ Kesalahan acak/error term .

d. Uji Koefisien Determinasi $\left(\mathbf{R}^{2}\right)$

Koefisien determinasi $\left(\mathrm{R}^{2}\right)$ dimaksudkan untuk mengetahui seberapa besar

variabel independen berpengaruh terhadap variabel terikat Earning Per Share (Y) sebagai variabel dependen. Setiap tambahan satu variabel independen, maka $\mathrm{R}^{2}$ pasti akan meningkat tanpa melihat apakah variabel tersebut berpengaruh secara signifikan terhadap variabel dependen. Nilai koefisien determinasi memiliki interval 0 sampai 1 . Semakin kecil nilai Adjusted $R$ Square maka semakin terbatas kemampuan variabel independen dalam menjelaskan variasi variabel dependen.

\section{Pembahasan Hasil Penelitian}

Tabel 1: Ringkasan Hasil Analisis Regresi Linear Berganda.

\begin{tabular}{llll}
\hline \multicolumn{1}{c}{ Variabel } & $\begin{array}{c}\text { Koefisien } \\
\text { Regresi }\end{array}$ & Nilai Sign & Simpulan \\
\hline X1= Pertumbuhan laba & 8,714 & $0,399>0,05$ & $\begin{array}{l}\text { Tidak } \\
\text { berpengaruh }\end{array}$ \\
X2= Perputaran persediaan & $-68,659$ & $0,513>0,05$ & $\begin{array}{l}\text { Tidak } \\
\text { berpengaruh }\end{array}$ \\
X3= ROE & & & Berpengaruh \\
X4= ROA & $-92,966$ & $0,029<0,05$ & Berpengaruh \\
Nilai Signifikan uji F $=0,000$ & 876,860 & $0,000<0,05$ & \\
Nilai R-square $=0,774$ & & & \\
\hline
\end{tabular}

\section{Pengaruh Pertumbuhan Laba terhadap Laba Per Lembar Saham (EPS)}

Hasil dari pengujian hipotesis yang dilakukan dengan menggunakan program SPSS memperoleh beberapa pernyataan. Pertumbuhan laba tidak berpengaruh signifikan terhadap laba per lembar saham (Earning Per Share). Hal ini berarti bahwa perusahaan tidak dapat menghasilkan keuntungan atau mengalami penurunan pertumbuhan laba. Pengaruh negatif ini diakibatkan kurang efektifnya penggunaan modal perusahaan dalam menghasilkan laba perusahaan, sehingga dana yang diperoleh di tahun yang akan datang mengalami penurunan.

\section{Pengaruh Perputaran Persediaan terhadap Laba Per Lembar Saham (EPS)}

Hasil dari pengujian hipotesis yang dilakukan dengan menggunakan program SPSS menunjukkan perputaran persediaan tidak memiliki pengaruh positif signifikan terhadap laba per lembar saham (EPS). Artinya jika perputaran persediaan meningkat maka laba per lembar saham akan meningkat, namun peningkatan tersebut tidak signifikan, yang berarti walaupun ada peningkatan namun peningkatan tersebut hanya sedikit. 


\section{Pengaruh Return On Equity (ROE) terhadap Laba Per Lembar Saham (EPS)}

Hasil dari pengujian hipotesis melalui program SPSS menyatakan bahwa Return On Equity (ROE) berpengaruh negatif dan signifikan terhadap laba per lembar saham (EPS) yang berarti bahwa perusahaan tidak dapat menghasilkan keuntungan dengan modal sendiri yang dapat menguntungkan pemegang saham. Hal ini dikarenakan investor melihat nilai ROE yang tinggi belum tentu disebabkan perusahaan memperoleh keuntungan yang tinggi terkadang dapat membahayakan kondisi perusahaan. Nilai ROE yang tinggi belum tentu disebabkan oleh perusahaan yang memiliki keuntungan yang tinggi, tetapi dapat disebabkan oleh hutang perusahaan lebih besar dari pada modal sendiri, sehingga perusahaan tidak dapat mendapatkan laba secara maksimal karena harus membayar hutang beserta bunganya, hal ini dapat mengurangi pendapatan perusahaan dan berdampak pada laba per lembar saham (EPS). Kondisi ini juga membahayakan pemilik modal jika perusahaan tidak dapat membayar hutang dan bunganya.

\section{Pengaruh Return On Asset (ROA) terhadap Laba Per Lembar Saham (EPS)}

Hasil dari pengujian hipotesis melalui program SPSS menyatakan bahwa Return On Asset (ROA) berpengaruh positif dan signifikan terhadap laba per lembar saham (EPS). Hasil pengujian ini sejalan dengan penelitian Puspita, dkk, (2015) yang menyatakan bahwa Return On Asset (ROA) berpengaruh positif dan signifikan terhadap laba per lembar saham (EPS). Dalam konteks nilai ROA yang tinggi, untuk mengetahui kinerja perusahaan dalam menghasilkan laba dengan memanfaatkan aktiva yang dimiliki, nilai ROA yang tinggi membuktikan bahwa perusahaan berhasil memanfaatkan aktiva yang dimilikinya dengan baik. Sehingga semua hal ini akan menyebabkan meningkatnya nilai laba per lembar saham (EPS) pada perusahaan industri barang konsumsi sub sektor makanan dan minuman (food and beverages).

\section{Kesimpulan}

Berdasarkan hasil pembahasan pada penelitian ini diperoleh kesimpulan sebagai berikut:

1. Berdasarkan hasil uji $\mathrm{t}$ atau secara parsial variabel pertumbuhan laba tidak memiliki pengaruh secara signifikan terhadap laba per lembar saham (EPS).

2. Berdasarkan hasil uji t variabel perputaran persediaan tidak memiliki pengaruh secara signifikan terhadap laba per lembar saham (EPS).

3. Berdasarkan hasil uji t variabel Return On Equity (ROE) memiliki pengaruh negatif dan signifikan terhadap laba per lembar saham (EPS).

4. Berdasarkan hasil uji t atau secara parsial variabel Return On Asset (ROA) memiliki pengaruh positif dan signifikan terhadap laba per lembar saham (EPS) dan menunjukan paling besar pengaruhnya terhadap laba per lembar saham (EPS).

5. Berdasarkan uji $\mathrm{F}$ atau secara simultan variabel pertumbuhan laba, perputaran persediaan, Return On Equity (ROE), dan Return On Asset (ROA) secara bersama-sama berpengaruh terhadap laba per lembar saham (EPS).

6. Dari hasil penelitian diperoleh nilai $A d$ justed $R$ Square adalah 0,774. Hal ini berarti bahwa 77,4 persen laba per lembar saham (EPS) dipengaruhi oleh keempat variabel yaitu pertumbuhan laba, perputaran persediaan, Return On Equity (ROE), dan Return On Asset (ROA). Sedangkan sisanya dipengaruhi oleh variabel lain yang tidak diteliti.

\section{Saran}

1. Bagi peneliti lain sebaiknya menambah variabel independen seperti perputaran modal kerja dan memperluas periode penelitian agar dapat mendapatkan hasil yang lebih maksimal. 
2. Bagi perusahaan hendaknya mampu untuk memahami sumber-sumber dana yang dapat digunakan untuk memaksimalkan aktivitas perusahaan, sehingga laba perusahaan meningkat.

3. Bagi investor sebaiknya lebih berhati-hati dalam memilih perusahaan yang akan dijadikan sebagai tempat investasi. Informasi baru sangat penting untuk menentukan keputusan berinvestasi agar dapat memperoleh keuntungan yang maksimal.

\section{Daftar Pustaka}

Ahmad, Fadliyan, dkk. (2014). Perputaran Piutang, Perputaran Persediaan, dan Struktur Modal terhadap Laba Per Lembar Saham pada Industri Semen yang Go Public. Jurnal EMBA. Vol. 2 No. 2, Juni. Hal. 1559-1569.

Agus,Sartono. 2010. Manajemen Keuangan Teori dan Aplikasi. Edisi keempat. Yogyakarta: BPEF.

Amaliah, N., Sri, A, dan Surdjono. 2016. Pengaruh Rasio Profitabilitas dan Leverages terhadap Earning Per Share (E$P S)$. Jurnal Ekonomi dan Bisnis Islam. Vol. 2 No. 01, Juni. Hal. 77-90.

Andrea, Milka E. (2010). Penggunaan Informasi Keuangan untuk Memprediksi Keuntungan Investasi bagi Investor pada Perusahaan Rokok yang Go Public di BEI. Skripsi. Jawa Timur: Fakultas Ekonomi Universitas Pembangunan Nasional "Veteran".

Ayu, E. R, dan Susilo, J. W. (2014). Pengaruh Perputaran Kas, Perputaran Piutang dan Perputaran Persediaan terhadap Profitabilitas Perusahaan Manufaktur. Jurnal Ilmu Manajemen. Vol. 2 No. 4, Oktober. Hal. 1444-1455.

Bambang, Riyanto. 2001. Dasar-Dasar Pembelanjaan Perusahaan. Edisi Keempat. Yogyakarta: BPEF.
Brigham, dan Houston. 2010. Dasar-Dasar Manajemen keuangan. Edisi 11. Jakarta: Salemba Empat.

Citra, Feri, F. (2014). Pengaruh Return On Equity (ROE), Return On Asset (ROA), dan Net Profit Margin (NPM) terhadap Harga Saham pada Sektor Real Estate and Property di Bursa Efek Indonesia Periode 2008-2011. Jurnal Bisnis dan Ekonomi.Vol. 5 No. 1, Juni. Hal. 19-30.

Darma, Emile. S, Agus Tri B. (2015). Statistika, Aplikasi pada Ekonomi, Bisnis dan Penelitian. Yogyakarta: Danisa Media.

Darmadji Tjipto dan Hendry M Fakhruddin. 2001. Pasar Modal di Indonesia. Jakarta: Salemba Empat.

Darmadji dan Fakhrudin. 2012. Pasar Modal di Indonesia. Edisi ketiga. Jakarta: Salemba Empat.

Diaz, Rafika dan Jufrizen. 2014. Pengaruh Return On Assets (ROA) dan Return On Equity (ROE) terhadap Earning Per Share (EPS) pada Perusahaan Asuransi yang terdaftar di Bursa Efek Indonesia. Jurnal Ekonomi dan Bisnis. Vol. 14 No. 02, Oktober. Hal. 127-134.

Erari, Anita. 2014. Analisis pengaruh Current Ratio, Debt to Equity Ratio, dan Return On Asset terhadap Return Saham pada Perusahaan Pertambangan di Bursa Efek Indonesia. Jurnal Manajemen dan Bisnis. Vol. 5 No. 2, September. Hal 174-191.

Fahmi, Irham. 2012. Manajemen Investasi: Teori dan Soal Jawab. Jakarta: Salemba Empat.

Fatmasari, Freni, dkk. (2015). Penggunaan Informasi Keuangan untuk Memprediksi Keuntungan Investasi bagi Investor di Pasar Modal (Studi Kasus pada Perusahaan Manufaktur Sektor Barang Industri Barang Konsumsi Sub Sektor Makanan 
dan Minuman di Bursa Efek Indonesia Tahun 2011-2014). Ejournal Riset Mahasiswa. Vol. xx No. xx. Hal 1-20.

Ghozali, Imam. 2011. Aplikasi Analisis Multivariate dengan Program IBM SPSS 19 (edisi kelima). Semarang: Badan Penerbit Undip.

Hanum, Zulia. 2009. Pengaruh Return On Asset (ROE), Return On Equity (ROE), dan Earning Per Share (EPS) terhadap Harga Saham pada Perusahaan Otomotif yang Terdaftar di Bursa Efek Indonesia Periode 2008-2011. Jurnal manajemen dan Bisnis. Vol. 8 No. 2, April. ISSN: 1693-7619.

Harahap, Sofyan Safri. 2005. Teori Akuntansi. Jakarta: PT. Raja Grafindo Persada.

Ikatan Akuntan Indonesia. 2009. Standar Akuntansi Keuangan. Jakarta: Salemba Empat.

Irmawati, Fitri. 2011. Pengaruh Informasi Keuangan terhadap Harga Saham pada Perusahaan Makanan dan Minuman yang Go Public yang Terdaftar di Bursa Efek Indonesia. Skripsi.

Jeni, Rengga, E, S. (2014). Pengaruh DER, EPS, ROA terhadap Harga Saham pada Perusahaan Telekomunikasi di BEI. Jurnal Ilmu dan Riset Manajemen. Vol. 3 No. 9.

Mamduh. M. Hanafi dan Abdul Halim. 2002. Analisis Laporan keuangan, Yogyakarta: UPP AMK YKPN.

Nazaruddin, L. dan Agus, T. (2016). Analisis Statistik dengan SPSS. Yogyakarta: Danisa Media.

Nazir, Mohamad. 1999. Metode Penelitian. Cetakan Ketiga. Jakarta: Ghalia Indonesia.
Priaditama, Pungky. 2010. Penggunaan Informasi Keuangan untuk Memprediksi Keuntungan Investasi bagi Investor pada Perusahaan Automotive and Components yang Go Public di BEI. Skripsi. Jawa Timur: Fakultas Ekonomi Universitas Pembangunan Nasional "Veteran".

Purnomo, Didi A. (2013). "Investasi di Indonesia”. Makalah Manajemen dan Bisnis. Cikarang: Sekolah Tinggi Manajemen dan Informatika Komputer Pranata Indonesia.

Puspita, M., Budi, P, dan Yenfi. 2015. Analisis Pengaruh Net Sales dan Return On Assets terhadap Earning Per Share. Jurnal Ilmiah Akuntansi Bisnis dan Keuangan (JIABK). Vol. 3 Issue 2, November. Hal 1-10.

Putri, Mutiara. 2013. Pengaruh Kinerja Keuangan terhadap Return Saham (pada Perusahaan Food and Beverages yang Terdaftar di Bursa Efek Indonesia Periode 2006-2010). Skripsi. Bandung: Fakultas Bisnis dan Manajemen Universitas Widyatama.

Rice, Agustina. 2016. Analisis Faktor-Faktor yang Mempengaruhi Pertumbuhan Laba dengan Ukuran Perusahaan sebagai Variabel Moderating pada Perusahaan Manufaktur yang Terdaftar di Bursa Efek Indonesia. Jurnal Wira Ekonomi Mikroskil. Vol. 6 No. 1, April. Hal. 85101.

Ridia, B dan Budiarti, A. (2016). Pengaruh Rasio Keuangan terhadap Pertumbuhan Laba pada Perusahaan Pertambangan Logam di BEI. Jurnal Ilmu dan Riset Manajemen. Vol. 5 No. 6, Juni. Hal. 118.

Sjahrial, Dermawan. 2012. Pengantar Manajemen Keuangan. Edisi keempat. Jakarta: Mitra Wacana Media. 
Syamsudin, Lukman. 2009. Manajemen keuangan Perusahaan. Edisi Baru. Jakarta: PT. Raja Grafindo Persada.

Weston, J. F dan E. F. Brigham. 2001. Fundamental of Finincial Statement: DasarDasar Manajemen Keuangan. Terjemahan Alfonus Sirait. Jakarta: Erlangga.

Widya, Ismi Ningrum. 2015. Pengaruh Kinerja Keuangan Perusahaan Manufak- tur terhadap harga Saham di Bursa Efek Indonesia. Jurnal Ilmu dan Riset Manajemen. Vol. 4 No. 2, Februari. Hal. 1-17.

Widyawati, I., Perengkuan T, Victoria U. (2016). Pengaruh Current Ratio dan Struktur Modal terhadap Laba Per Lembar Saham pada Perusahaan Pertambangan Batu Bara yang Terdaftar di BEI. Jurnal Berkala Ilmiah Efisiensi. Vol. 16 No. 1. 


\title{
ANALISIS FAKTOR-FAKTOR YANG MEMPENGARUHI AKUNTAN BEREGISTER BERPROFESI SEBAGAI AKUNTAN PUBLIK
}

\author{
Neneng Salmiah ${ }^{1}$, Arista Natia Afriany ${ }^{2}$ \\ ${ }^{1}$ Universitas Lancang Kuning, Jl. DI Pandjaitan KM. 08 Rumbai, Pekanbaru, Riau, \\ ${ }^{2}$ Universitas PGRI Yogyakarta, Jl. PGRI I No. 117 Sonosewu, Bantul, Yogyakarta. \\ e-mail: tachi.neneng@yahoo.com
}

\begin{abstract}
This research aimed at empirically testing of the factors that affect the registered accountant as members of IAI in Pekanbaru worked as a public accountant that focused to test the effect of the USAP cost, USAP process and occupational risk with variable electoral career as a public accountant. USAP cost, USAP process and occupational risk variables are as independent variables, associated with various assumptions. This research had 45 samples and used purposive sampling as the technique. Located on Pekanbaru area and using primary data. The data method is by spreading some questionnaires. Measurements of variables performed with Likert scale. Data analysis was conducted through quantitative analysis. Quantitative data analysis was performed by multiple regression analysis and hypothesis testing was done by t-test. The results obtained show that the USAP process and occupational risk significantly influence the selection of a career as a public accountant, USAP cost influence on elections as a public accounting career, but the effect is not significant. Overall USAP cost, USAP process and occupational risk jointly significant effect on elections to the selection of a career as a public accountant.
\end{abstract}

Key words: Public accountant, USAP cost, USAP process, occupational risk.

\begin{abstract}
Abstrak
Penelitian ini dilakukan untuk menganalisis faktor-faktor yang mempengaruhi akuntan beregister yang terdaftar sebagai anggota IAI di Pekanbaru berprofesi sebagai akuntan publik secara empiris. Penelitian ini difokuskan untuk menguji pengaruh antara variabel-variabel biaya USAP, proses USAP, resiko pekerjaan dengan variabel pemilihan karir sebagai akuntan publik. Variabel biaya USAP, variabel proses USAP dan Variabel resiko pekerjaan sebagai variabel independen, dihubungkan dengan berbagai asumsi. Sampel penelitian berjumlah 45 responden yang diambil dengan teknik purposive sampling. Lokasi penelitian adalah di wilayah Pekanbaru. Jenis data yang digunakan merupakan data primer yang didapat dengan menyebarkan kuesioner. Pengukuran variabel dilakukan dengan skala Likert. Analisis data dilakukan melalui analisis kuantitatif. Analisis data kuantitatif dilakukan dengan analisis regresi berganda dan pengujian hipotesis dilakukan dengan melakukan uji-t. Hasil yang diperoleh menunjukkan bahwa proses USAP dan resiko pekerjaan berpengaruh signifikan terhadap pemilihan karir sebagai akuntan publik, biaya USAP berpengaruh terhadap pemilihan karir sebagai akuntan publik, akan tetapi pengaruhnya tidak signifikan. Secara keseluruhan biaya USAP, proses USAP, dan resiko pekerjaan secara bersama-sama berpengaruh signifikan terhadap pemilihan terhadap pemilihan karir sebagai akuntan publik.
\end{abstract}

Kata kunci: Akuntan publik, biaya USAP, proses USAP, resiko pekerjaan. 


\section{Pendahuluan}

Akuntan publik adalah akuntan yang telah memperoleh izin dari menteri keuangan untuk memberikan jasa akuntan publik di Indonesia. Ketentuan mengenai akuntan publik di Indonesia diatur dalam Undang-Undang Republik Indonesia Nomor 5 tahun 2011 tentang Akuntan Publik dan Peraturan Menteri Keuangan Nomor 17/PMK.01/2008 tentang Jasa Akuntan Publik. Setiap akuntan publik wajib menjadi anggota Institut Akuntan $\mathrm{Pu}-$ blik Indonesia (IAPI), asosiasi profesi yang diakui oleh Pemerintah.

Akuntan publik berfungsi untuk mengawasi, mengoreksi dan mengarahkan sebuah perusahaan tentunya untuk lebih baik. Saat ini jumlah akuntan publik tidak sebanding dengan banyaknya organisasi-organisasi yang membutuhkan jasa audit. Jumlah akuntan publik di Indonesia masih sangat sedikit dan rata-rata pertumbuhan akuntan publik sampai dengan 2011 yaitu 4,6\% serta tidak sebanding dengan banyaknya laporan keuangan yang harus diaudit.

Tidak sebandingnya jumlah akuntan publik dengan banyaknya laporan keuangan yang harus diaudit dapat digambarkan dengan kondisi sebagai berikut: sejak disahkannya Undang-Undang Badan Hukum Pendidikan (UU BHP), akuntan publik harus mengaudit laporan keuangan semua Perguruan Tinggi Negeri (PTN) dan Perguruan Tinggi Swasta (PTS). Sedikitnya ada 87 PTN dan 2.700 PTS yang laporan keuangannya harus diaudit. Selain itu, jika menjelang pemilu, akuntan publik juga harus mengaudit laporan keuangan partai politik, mulai dari parpol di pusat hingga tingkat kabupaten. Ketika diadakan Pemilihan Kepala Daerah (Pilkada) pada suatu daerah baik dalam pemilihan $\mathrm{Gu}-$ bernur maupun Walikota atau Bupati, akuntan publik juga harus mengaudit kekayaan yang dimiliki oleh calon kepala daerah tersebut. Disamping itu dalam UU No.4 tahun 2007 Perseroan Terbatas Pasal 68 menyatakan bahwa direksi wajib menyerahkan laporan keuangan Perseroan kepada akuntan publik untuk diaudit apabila: a) kegiatan usaha perseroan adalah menghimpun dana/dan menge- lola dana masyarakat; b) perseroan menerbitkan surat pengakuan hutang kepada masyarakat; c) perseroan merupakan perseroan terbu$\mathrm{ka}$; d) perseroan merupakan persero; e) perseroan mempunyai aset dan/atau jumlah peredaran usaha dengan jumlah nilai paling sedikit Rp 50.000.000.000,-; dan f) diwajibkan oleh peraturan perundang-undangan. Dengan demikian jumlah akuntan publik di Indonesia masih sangat sedikit dan tidak sebanding dengan banyaknya laporan keuangan yang harus diaudit.

Tantangan yang akan dihadapi Akuntan Publik Indonesia semakin besar dengan akan dilaksanakannya Asean Economic Community (AEC) pada tahun 2015 mendatang. AEC adalah salah satu dari 3 pilar konsep ASEAN Integration yang telah disetujui bersama oleh Kepala Negara dari 10 negara anggota ASEAN dalam pertemuan di Bali tahun 2003 yang dikukuhkan lewat Declaration of ASEAN Concord II atau yang dikenal dengan Bali Concord II. Konsep utama dari AEC adalah menciptakan ASEAN sebagai sebuah pasar tunggal dan kesatuan basis produksi dimana terjadi free flow atas barang, jasa, faktor produksi, investasi dan modal serta penghapusan tarif bagi perdagangan antar negara ASEAN yang kemudian diharapkan dapat mengurangi kemiskinan dan kesenjangan ekonomi diantara negara-negara anggotanya melalui sejumlah kerjasama yang saling menguntungkan. Salah satu yang akan diperdagangkan secara bebas (free flow) dalam AEC tersebut adalah jasa akuntan publik. Hal ini tentu saja menjadi ancaman sekaligus tantangan bagi akuntan publik di Indonesia terutama dengan kondisi sedikitnya jumlah akuntan beregister yang berprofesi sebagai akuntan publik/Kantor Akuntan Publik (KAP) dan KAP yang ada sebagian besar dikelola oleh akuntan publik yang berusia diatas 59 tahun. Data tersebut mengindikasikan telah terjadinya kelangkaan (scarcity) di Profesi Akuntan Publik di Indonesia. Penyebab kelangkaan dan masalah regenerasi tersebut disebabkan oleh beberapa faktor. Salah satu faktornya adalah jumlah lulusan USAP yang masih sedikit, padahal syarat utama untuk memperoleh izin praktek sebagai akuntan publik adalah harus sudah 
memiliki Certified of Public Accountant (CPA). (Gani dan Leo; 2009).

Syarat utama yang akan memilih berprofesi sebagai akuntan publik adalah sarjana ekonomi jurusan akuntansi dan non akuntansi yang telah mengikuti Pendidikan Profesi Akuntansi (PPA) sehingga berhak mendapat gelar Akuntan (AK) dan terdaftar pada Kementerian Keuangan Republik Indonesia. Berdasarkan data yang diperoleh jumlah akuntan beregister sampai dengan tahun 2012 adalah sebanyak 51.700 akuntan. Jika dibandingkan dengan jumlah akuntan publik/KAP sampai dengan 2012 (1.015 KAP) maka dapat kita simpulkan bahwa jumlah akuntan beregister yang berprofesi sebagai akuntan publik di Indonesia yaitu hanya 1,96\%. Hal ini merupakan jumlah yang sangat kecil mengingat kebutuhan akuntan publik sangat besar jika dibandingkan dengan banyaknya laporan keuangan yang wajib diaudit oleh akuntan publik serta kesiapan akuntan publik Indonesia dalam menghadapi Asean Economic community yang akan dilaksanakan 2015.

Berdasarkan data di atas, penulis melihat kecilnya jumlah akuntan beregister yang berprofesi sebagai akuntan publik $(1,96 \%)$ sedangkan peluang profesi sebagai akuntan publik tersebut terbuka sangat besar. Hal ini tentu menimbulkan tanda tanya besar bagi penulis yaitu faktor-faktor apa yang menyebabkan rendahnya minat akuntan beregister berprofesi sebagai akuntan publik. Disamping itu untuk dapat menjalankan profesinya sebagai akuntan publik di Indonesia, seorang akuntan beregister harus lulus dalam ujian profesi yang dinamakan Ujian Sertifikasi Akuntan Publik (USAP) dan kepada lulusannya berhak memperoleh sebutan "CPA Indonesia" (sebelum tahun 2007 disebut "Bersertifikat Akuntan Publik" atau BAP). Sertifikat akan dikeluarkan oleh IAPI. Sertifikat akuntan publik tersebut merupakan salah satu persyaratan utama untuk mendapatkan izin praktek sebagai akuntan publik dari Kementerian Keuangan.

Proses yang harus dilalui untuk menjadi akuntan publik setelah memperoleh gelar Akuntan dimana akuntan beregister tersebut harus mengikuti Indonesia CPA Exam (Certified Public Accountant) atau biasa disebut Ujian Sertifikasi Akuntan Publik (USAP). USAP diselenggarakan sebanyak tiga kali dalam satu tahun yaitu pada bulan Februari, Juni dan Oktober. Mata ujian yang diujikan adalah Akuntansi dan Pelaporan Keuangan, Lingkungan Bisnis, Hukum Komersial dan Perpajakkan, Auditing dan Assurance, Akuntansi Manajemen, Manajemen Keuangan dan Sistem Informasi. Biaya yang harus dikeluarkan untuk mengikuti ujian tersebut pun sangat banyak. Biaya tersebut meliputi biaya pendaftaran Rp. 500.000 (satu kali), biaya ujian pertama Rp. 3.500.000 dan biaya ujian jika mengulang Rp. 1.000 .000 (per mata ujian). Peserta yang mengikuti USAP diberi kesempatan selama 24 bulan untuk menyelesaikan seluruh mata ujian sejak pertama kali mengikuti ujian. Peserta yang tidak lulus secara keseluruhan dalam waktu 24 bulan, maka mata ujian yang telah lulus dianggap gugur. Bagi peserta yang ingin mengikuti USAP kembali, maka peserta harus mengulang seluruh mata ujian. Dengan demikian, memang sangat sulit untuk lulus dari USAP. Jika mahasiswa tersebut bisa lulus dari ujian tersebut maka mahasiswa tersebut bisa mendapatkan sebutan Indonesia CPA. Begitu banyaknya prosedur yang harus dilalui, lamanya proses dan dibutuhkannya biaya yang besar untuk berprofesi menjadi akuntan publik menjadikan faktor rendahnya minat lulusan mahasiswa akuntansi untuk berprofesi menjadi akuntan public (Cahyo, 2011).

Penelitian ini bukanlah penelitian yang baru pertama kali dilakukan di Indonesia. Beberapa penelitian terdahulu untuk mengetahui minat akuntan beregister berprofesi sebagai akuntan publik menunjukkan hasil yang berbeda Rahayu, dkk. (2003) dalam penelitiannya menemukan bahwa mahasiswa dan mahasiswi akuntansi dari universitas negeri dan universitas swasta banyak yang berminat untuk memilih karir sebagai akuntan perusahaan. Hasil penelitiannya juga menunjukkan bahwa terdapat perbedaan pandangan mengenai penghargaan finansial, pelatihan profesional, pengakuan profesional, lingkungan kerja, dan pertimbangan pasar kerja, sedangkan 
untuk faktor nilai-nilai sosial dan personalitas tidak terdapat perbedaan pandangan. Berdasarkan gendernya, maka perbedaan persepsi/ pandangan mahasiswa akuntansi terlihat pada faktor pelatihan profesional dan lingkungan kerja, sedangkan untuk faktor penghargaan finansial, pengakuan profesional, nilai-nilai sosial, pertimbangan pasar kerja, dan personalitas tidak terdapat perbedaan pandangan.

Lara Absara Aprilyan (2011), melakukan penelitian untuk mengetahui dan menganalisis mengenai faktor-faktor apa saja yang mempengaruhi mahasiswa akuntansi dalam pemilihan karir menjadi Akuntan Publik. Faktor-faktor yang mempengaruhi terhadap pemilihan karir menjadi Akuntan Publik diukur dengan variabel nilai intrinsik pekerjaan, gaji, lingkungan kerja, pelatihan profesional, pengakuan profesional, nilai-nilai sosial, pertimbangan pasar kerja, dan personalitas. Hasil analisis ini menunjukkan bahwa secara simultan variabel nilai intrinsik pekerjaan, gaji, lingkungan kerja, pelatihan profesional, pengakuan profesional, nilai-nilai sosial, pertimbangan pasar kerja, dan personalitas berpengaruh signifikan terhadap pemilihan karir menjadi akuntan publik oleh mahasiswa akuntansi, namun secara parsial variabel lingkungan kerja tidak berpengaruh secara signifikan terhadap pemilihan karir menjadi akuntan publik oleh mahasiswa akuntansi, sedangkan variabel nilai intrinsik pekerjaan, gaji, pelatihan profesional, pengakuan profesional, nilai-nilai sosial, pertimbangan pasar kerja, dan personalitas masing-masing berpengaruh signifikan.

Harian Kompas terbitan Senin, 16 Maret 2009 dalam artikel yang ditulis oleh Nugroho Cahyo (3 Agustus 2011) menyatakan, Dewan Kehormatan Ikatan Akuntansi Publik Indonesia (IAPI), Sukrisno Agoes mengatakan bahwa profesi akuntan publik tidak diminati kalangan muda dan fresh graduate (sarjana baru). Faktor yang mempengaruhi sedikitnya minat lulusan mahasiswa akuntansi untuk menjadi akuntan publik yaitu resiko akuntan publik yang ditanggung sangat besar sedangkan penghasilannya tidak sesuai dengan beban resiko yang ditanggung oleh akuntan publik. Proses yang harus dilalui untuk menjadi akuntan publik yang sangat panjang dan sangat lama juga mempengaruhi rendahnya minat mahasiswa untuk berprofesi menjadi akuntan publik (Cahyo, 2011).

Penelitian ini merupakan pengembangan dari penelitian yang dilakukan oleh peneliti terdahulu. Perbedaan utama antara penelitian ini dengan penelitian terdahulu yaitu pada sampel yang diambil yaitu akuntan beregister yang terdaftar sebagai anggota Ikatan Akuntan Indonesia (IAI) Wilayah Pekanbaru. Variabel yang digunakan dalam penelitian ini berbeda dengan variabel penelitian terdahulu. Pada penelitian ini, peneliti akan meneliti tiga variabel, yaitu variabel resiko pekerjaan, biaya USAP dan proses USAP sebagaimana yang terdapat pada Cahyo (2011) terkait pernyataan yang disampaikan oleh Dewan Kehormatan Ikatan Akuntan Publik Indonesia (IAPI)-Sukrisno Agoes.

Berdasarkan data yang diperoleh dari PPAJP (Pusat Pembinaan Akuntan dan Jasa Penilai) di atas dan hasil penelitian yang berbeda-beda dari para peneliti terdahulu yang telah meneliti permasalahan yang sama serta pernyataan yang disampaikan Dewan Kehormatan IAPI yang terdapat dalam artikel Nugroho Cahyo (2011) maka penulis berusaha untuk menganalisis faktor-faktor yang mempengaruhi akuntan beregister di wilayah $\mathrm{Pe}$ kanbaru berprofesi sebagai akuntan publik. Dimana tujuan dari penelitian ini adalah untuk mengetahui faktor-faktor apakah yang mempengaruhi akuntan beregister berprofesi sebagai akuntan publik, melalui pengujian empiris mengenai pengaruh biaya Ujian Sertifikasi Akuntan Publik (USAP), proses USAP dan resiko pekerjaan terhadap pemilihan karir sebagai akuntan publik di Pekanbaru, baik pengujian secara terpisah maupun pengujian secara keseluruhan.

\section{Tinjauan Pustaka}

Beberapa penelitian yang menjadi landasan dalam penelitian ini adalah: Hammer dan Organ dalam Sofyandi dan Garniwa (2007) menyatakan bahwa persepsi adalah "the process by which people organize, interpret, experience, and process cues or 
material (inputs) received from the external environment", yang artinya persepsi adalah suatu proses dengan mana seseorang mengorganisasikan dalam pikirannya, menafsirkan, mengalami, dan mengolah pertanda atau segala sesuatu yang terjadi di lingkungannya. Selanjutnya Maslow mengemukakan bahwa kebutuhan dapat didefinisikan sebagai suatu kesenjangan atau pertentangan yang dialami antara suatu kenyataan dengan dorongan yang ada dalam diri, serta orang dewasa secara normal memuaskan kira-kira $85 \%$ kebutuhan fisiologis, $70 \%$ kebutuhan rasa aman, 50\% kebutuhan untuk memiliki dan mencintai, $40 \%$ kebutuhan harga diri, dan hanya $10 \%$ dari kebutuhan aktualisasi diri.

Teori dua faktor dikembangkan oleh Frederick Herzberg. Ia menggunakan teori Abraham Maslow sebagai titik acuannya. Herzberg melakukan penelitian tentang motivasi terhadap 200 akuntan dan insinyur yang dipekerjakan di berbagai perusahaan disekitar Pittsburgh, Pensylvinia. Masingmasing responden diminta menceritakan kejadian yang dialami oleh mereka baik yang menyenangkan (memberikan kepuasan) maupun yang tidak menyenangkan atau tidak memberikan kepuasan. Kemudian, hasil wawancara tersebut dianalisis dengan analisis isi (content analysis) untuk menentukan faktor-faktor yang menyebabkan kepuasan atau ketidakpuasan.

Dua faktor yang menyebabkan timbulnya rasa puas atau tidak puas menurut Herzberg, yaitu faktor pemeliharaan (maintenance factors) dan faktor pemotivasian (motivationnal factors). Faktor pemotivasian disebut pula dissatisfiers, hygiene factors, job context, extrinsic factors yang meliputi administrasi dan kebijakan perusahaan, kualitas pengawasan, hubungan dengan pengawas, hubungan dengan subordinate, upah, keamanan kerja, kondisi kerja, dan status. Sedangkan faktor pemotivasian disebut pula satisfier, motivators, job content, intrinsic factors yang meliputi dorongan berprestasi, pengenalan, kemajuan (advancement), work it self, kesempatan berkembang, dan tanggung jawab.
Teori ERG alderfer merupakan perluasan dari teori Maslow dan Herzberg. Teori ERG tidak terlalu berbeda dengan teori Maslow yang mengetengahkan tingkatan-tingkatan kebutuhan manusia. Teori ERG merupakan refleksi dari tiga dasar kebutuhan, yaitu: existence needs (kebutuhan eksistensi), relatedness needs (kebutuhan keterhubungan) dan growth needs (kebutuhan pertumbuhan).

Dauglas McGregor mengajukan dua pandangan yang berbeda tentang manusia: negatif dengan tanda label $X$ dan positif dengan tanda label Y. McGregor merumuskan asumsi-asumsi dan perilaku manusia dalam organisasi sebagai berikut: Teori X (negatif) merumuskan asumsi seperti: pertama, manusia sebenarnya tidak suka bekerja dan jika ada kesempatan maka ia akan menghindari atau bermalas-malasan dalam bekerja. Kedua, pada saat manusia tidak suka atau tidak menyukai pekerjaannya, mereka harus diatur dan dikontrol bahkan mungkin ditakuti untuk menerima sanksi hukum jika tidak bekerja dengan sungguh-sungguh. Ketiga, manusia akan menghindari tanggung jawabnya dan mencari tujuan formal sebisa mungkin. Keempat, kebanyakan manusia menempatkan keamanan di atas faktor lainnya yang berhubungan erat dengan pekerjaan dan akan menggambarkannya dengan sedikit ambisi.

Sedangkan Teori Y (positif) merumuskan asumsi seperti: pertama, manusia dapat memandang pekerjaan sebagai sesuatu yang wajar, lumrah dan alamiah baik tempat bermain atau beristirahat, dalam artian berdiskusi atau sekedar teman bicara. Kedua manusia akan melatih tujuan pribadi dan pengontrolan diri sendiri jika mereka melakukan komitmen yang sangat objektif. Ketiga, kemampuan untuk melakukan keputusan yang cerdas dan inovatif adalah tersebar secara meluas di berbagai kalangan tidak hanya selalu dari kalangan top manajemen atau dewan direksi.

Secara umum International Federation of Accountants (IFAC), menyatakan karakteristik profesi sebagai berikut (Media Akuntansi 28 September 2002): menguasai 
suatu keahlian tertentu yang diperoleh melalui pendidikan dan pelatihan, mempunyai kode etik dan standar keahlian kinerja (professional), memperoleh pengakuan masyarakat dengan adanya penggunaan gelar tertentu, serta mempunyai organisasi yang mewadahi dan memelihara seluruh kepentingan profesi tersebut.

Menurut Pusat Pembinaan Akuntan dan Jasa Penilai (PPAJP) Kementerian Keuangan Republik Indonesia yang disampaikan pada acara sosialisasi UU No. 5 tahun 2011 tentang Akuntan Publik di Universitas Riau pada tanggal 12 Oktober 2012, analisis SWOT profesi akuntansi di Indonesia sebagai berikut:

1. Kekuatan.

a. Kesiapan asosiasi profesi akuntansi untuk internasionalisasi (anggota IFAC).

b. Tingkat kepatuhan profesi terhadap regulasi di Indonesia.

c. Jumlah KAP yang kerjasama dengan KAPA/OAA.

d. Reputasi KAP di Indonesia.

e. Peningkatan pendapatan KAP.

f. Jumlah profesi akuntansi yang semakin meningkat.

g. Tingginya jumlah lulusan S1 Akuntansi.

2. Kelemahan.

a. Belum terdapat law enforcement perusahaan wajib audit.

b. Proses regenerasi AP yang kurang berjalan.

c. Minimnya jumlah partner yang dimiliki setiap KAP.

d. Rendahnya tingkat kelulusan ujian $\mathrm{C}$ PA Indonesia.

e. Rendahnya junlah AP di Indonesia.

f. Rendahnya kemampuan komunikasi akuntan dalam bahasa inggris.

g. Penghasilan yang kurang menarik bagi pemula.

3. Peluang.

a. Potensi pasar jasa profesi akuntansi Indonesia masih sangat luas.

b. Pertumbuhan ekonomi Indonesia dan demand profesi akuntansi cukup tinggi. c. Rencana pembentukan AEC 2015 .

4. Ancaman.

a. Rencana pembentukan AEC 2015.

b. Terbukanya kesempatan profesi akuntansi asing.

c. Jumlah profesi akuntansi asing yang sangat besar

d. Di Indonesia, persyaratan untuk dapat menjalankan suatu praktik sebagai akuntan publik diatur dalam pasal $6 \mathrm{UU}$ Akuntan Publik (PPAJP Kementerian Keuangan RI, 2012).

Kualifikasi yang dibutuhkan untuk dapat mengikuti pendidikan profesi akuntan publik adalah seseorang yang memiliki pendidikan minimal sarjana strata 1 (S-1), diploma IV (D-IV), atau yang setara. Persyaratan lain untuk menjadi CPA Indonesia adalah calon peserta ujian sertifikasi profesi AP harus telah menguasai common body professionl knowledge di bidang akuntansi. Common body of professional knowledge mengacu kepada International Education Standard (IES) yang diterbitkan oleh International Accounting Education Standard Board IFAC. Content of professional accounting $e$ ducation mencakup akuntansi keuangan dan pengetahuan terkait, pengetahuan organisasi dan bisnis, pengetahuan dan kompetensi teknologi informasi. Common body professionnal knowledge dapat diperoleh melalui beberapa jalur. Pathways menjadi CPA Indonesia adalah sebagai berikut :

- Jalur 1:

Berpendidikan strata 1 atau D IV di bidang akuntansi dengan pengalaman kerja di bidang akuntansi minimal 3 tahun + lulus USAP.

- Jalur 2:

Berpendidikan strata 2 di bidang akuntansi (MAKSI) dengan pengalaman kerja di bidang akuntansi minimal 2 tahun + lulus USAP

- Jalur 3:

Menyelesaikan pendidikan profesi akuntan publik (PPAP) + pengalaman kerja di bidang akuntansi minimal 2 tahun.

a. PPAP diselenggarakan oleh perguruan tinggi yang telah diakreditasi oleh asosiasi profesi akuntan publik. 
b. PPAP mencakup pendidikan dan ujian sertifikasi (USAP).

c. PPAP dapat diselenggarakan sebagai bagian dari PPAk atau program tersendiri.

d. Syarat: S1/DIV di bidang akuntansi atau S1/DIV non akuntansi dengan matrikulasi.

- Jalur 4:

Berpendidikan strata 1 atau D IV di bidang akuntansi dan menyelesaikan PPAk konsentrasi Akuntan Publik + lulus USAP.

- Jalur 5:

Bagi yang telah lulus ujian sertifikasi akuntan publik di luar negeri dan menjadi anggota asosiasi profesi akuntan publik dari negara lain (ACCA, CPA Australia, ICAEW, dll) wajib melakukan penyetaraan ujian sertifikasi kepada Asosiasi Profesi Akuntan Publik (mengikuti ujian subyek tertentu guna menyesuaikan dengan konten lokal).

Seluruh calon peserta USAP diwajibkan untuk membayar uang pendaftaran ujian pada saat mengembalikan formulir pendaftaran. Peserta yang dinyatakan lolos proses pendaftaran akan menerima Formulir Pembayaran Biaya Ujian (FPBU) sebagai dasar penyetoran biaya ujian. Calon peserta yang dinyatakan berhak untuk mengikuti ujian diwajibkan membayar biaya ujian dalam waktu 6 bulan sejak diberikannya FPBU atau paling lambat 3 minggu sebelum tanggal ujian. Apabila dalam waktu yang ditentukan calon peserta belum melunasi biaya ujian, maka calon peserta yang ingin mengikuti ujian diwajibkan untuk melakukan pendaftaran ulang. Menurut Dewan Sertifikasi IAPI, biaya untuk mengikuti USAP terdiri dari biaya pendaftaran sebesar Rp 1.000.000,-, biaya ujian bagi peserta baru sebesar Rp 6.000.000,- untuk 4 mata ujian. Sedangkan bagi peserta transfer atau mengulang, biaya ujian sebesar Rp 1.500.000,- per mata ujian. Begitu banyaknya prosedur yang harus dilalui, lamanya proses dan dibutuhkannya biaya yang besar untuk berprofesi menjadi akuntan publik menjadikan faktor rendahnya minat lulusan mahasiswa akuntansi untuk berprofesi menjadi akuntan publik (Cahyo, 2011).

Untuk dapat menjalankan profesinya sebagai akuntan publik di Indonesia, seorang akuntan beregister harus lulus dalam ujian profesi yang dinamakan Ujian Sertifikasi Akuntan Publik (USAP) dan kepada lulusannya berhak memperoleh sebutan "CPA Indonesia" (sebelum tahun 2007 disebut "Bersertifikat Akuntan Publik" atau BAP). Sertifikat akan dikeluarkan oleh IAPI. Sertifikat akuntan publik tersebut merupakan salah satu persyaratan utama untuk mendapatkan izin praktek sebagai akuntan publik dari Kementerian Keuangan. Proses yang harus dilalui untuk menjadi akuntan publik setelah memperoleh gelar Akuntan dimana akuntan beregister tersebut harus mengikuti Indonesia CPA Exam (Certified Public Accountant) atau biasa disebut Ujian Sertifikasi Akuntan Publik (USAP). USAP diselenggarakan sebanyak tiga kali dalam satu tahun yaitu pada bulan Pebruari, Juni dan Oktober. Mata ujian yang diujikan adalah Akuntansi dan Pelaporan Keuangan, Lingkungan Bisnis, Hukum Komersial dan Perpajakan, Auditing dan Assurance, Akuntansi Manajemen, Manajemen Keuangan dan Sistem Informasi. Peserta yang mengikuti USAP diberi kesempatan selama 24 bulan untuk menyelesaikan seluruh mata ujian sejak pertama kali mengikuti ujian. Peserta yang tidak lulus secara keseluruhan dalam waktu 24 bulan, maka mata ujian yang telah lulus dianggap gugur. Bagi peserta yang ingin mengikuti USAP kembali, maka peserta harus mengulang seluruh mata ujian. Dengan demikian, memang sangat sulit untuk lulus dari USAP. Jika mahasiswa tersebut bisa lulus dari ujian tersebut maka mahasiswa tersebut bisa mendapatkan sebutan Indonesia CPA. Begitu banyaknya prosedur yang harus dilalui, lamanya proses dan dibutuhkannya biaya yang besar untuk berprofesi menjadi akuntan publik menjadikan faktor rendahnya minat lulusan mahasiswa akuntansi untuk berprofesi menjadi akuntan publik (Cahyo, 2011).

Harian Kompas terbitan Senin, 16 Maret 2009 dalam artikel yang ditulis oleh Nugroho Cahyo (3 Agustus 2011) menyatakan, 
Dewan Kehormatan Ikatan Akuntan Publik Indonesia (IAPI), Sukrisno Agoes mengatakan bahwa profesi akuntan publik tidak diminati kalangan muda dan fresh graduate (sarjana baru). Faktor yang mempengaruhi sedikitnya minat lulusan mahasiswa akuntansi untuk menjadi akuntan publik yaitu resiko akuntan publik yang ditanggung sangat besar sedangkan penghasilannya tidak sesuai dengan beban resiko yang ditanggung oleh akuntan publik.

Karir adalah seluruh pekerjaan yang dimiliki atau dilakukan oleh individu selama masa hidupnya. Karir merupakan pola dari pekerjaan dan sangat berhubungan dengan pengalaman (posisi, wewenang, keputusan, dan interpretasi subjektif atas pekerjaan), dan aktivitas selama masa kerja individu. Pengertian ini menekankan bahwa karir tidak berhubungan dengan kesuksesan atau kegagalan, namun lebih kepada sikap dan tingkah laku, dan kontinuitas individu dalam aktivitas yang berkaitan dengan pekerjaannya.

Tujuan karir adalah posisi di masa mendatang yang ingin dicapai oleh individu dalam pekerjaannya. Jadi keberhasilan karir tidak lagi diartikan sebagai penghargaan institusional dengan meningkatnya kedudukan dalam suatu hierarki formal. Apalagi pada saat ini karir telah mengalami pergeseran menuju karir tanpa batas (the boundaryless career). Kunci keberhasilan karir pada masa yang akan datang lebih dicerminkan dari pengalaman hidup seseorang daripada posisi yang dimilikinya.

Berdasarkan logika dari paparan di atas maka dikembangkan hipotesis atas penelitian ini, yaitu:

H1: Biaya USAP berpengaruh signifikan terhadap pemilihan karir sebagai Akuntan Publik oleh Akuntan Beregister.

H2: Proses USAP berpengaruh signifikan terhadap pemilihan karir sebagai Akuntan Publik oleh Akuntan Beregister.

H3: Resiko pekerjaan berpengaruh signifykan terhadap pemilihan karir sebagai Akuntan Publik oleh Akuntan Beregister.

H4: Biaya USAP, Proses USAP dan Resiko Pekerjaan secara bersama-sama berpe- ngaruh signifikan terhadap pemilihan karir sebagai Akuntan Publik oleh Akuntan Beregister.

\section{Metode Penelitian}

Populasi dalam penelitian ini adalah akuntan beregister yang terdaftar sebagai anggota IAI Wilayah Pekanbaru yang berjumlah 60 orang dan yang menjadi sampel dalam penelitian ini adalah semua anggota IAI Wilayah Pekanbaru yang memenuhi kriteria pengambilan sampel sehingga jumlah sampel sebanyak 45 orang. Teknik Pengambilan sampel dalam penelitian ini adalah purposive sampling. Purposive sampling adalah teknik penentuan sampel dengan pertimbangan tertentu. Adapun pertimbangan dalam penentuan sampel adalah:

1. Akuntan Register Negara (Akuntan beregister).

2. Akuntan beregister terdaftar sebagai anggota IAI Wilayah Pekanbaru pada tahun 2012.

3. Akuntan beregister yang terdaftar sebagai anggota IAI tahun 2012 tetapi tidak berprofesi sebagai akuntan pemerintah dan akuntan publik.

Sumber data yang digunakan dalam penelitian ini terdiri dari dua sumber yaitu:

a. Data primer yang merupakan persepsi akuntan beregister mengenai faktor-faktor yang mempengaruhi mereka dalam memilih profesi akuntan publik. Pengumpulan data yang digunakan dalam penelitian ini adalah a five point likertscale kuesioner dengan jawaban dari sangat setuju sampai dengan sangat tidak setuju.

b. Data sekunder, data yang penulis dapatkan selama penelitian yang berupa penelitian kepustakaan (libary research).

Variabel independen atau variabel bebas dalam penelitian ini yaitu:

- Biaya USAP (X1).

Biaya USAP yang relatif besar merupakan salah satu faktor yang potensial mempengaruhi perilaku akuntan beregister untuk memilih karir sebagai akuntan publik. Biaya USAP diuji dengan pertanyaan yang meminta persepsi akuntan 
beregister mengenai besarnya jumlah uang pendaftaran USAP, Biaya USAP per mata ujian bagi peserta baru, dan besarnya jumlah Biaya USAP per mata ujian bagi peserta mengulang.

- Proses USAP (X2).

Proses USAP yang panjang dan lama yaitu 24 tahun dan jika tidak lulus salah satu mata ujian mengakibatkan peserta USAP harus mengulang semua mata ujian. Hal ini tentu saja merupakan faktor yang potensial mempengaruhi pemilihan karir sebagai akuntan publik bagi akuntan beregister.

- Resiko Pekerjaan (X3).

Faktor yang mempengaruhi sedikitnya minat lulusan mahasiswa akuntansi untuk menjadi akuntan publik yaitu resiko akuntan publik yang ditanggung sangat besar sedangkan penghasilannya tidak sesuai dengan beban resiko yang ditanggung oleh akuntan publik. (Cahyo, 2011). Resiko yang dimaksud adalah akuntan publik harus mampu menjaga independensi dalam mengaudit laporan keuangan perusahaan yang diaudit.

Variabel dependen dalam penelitian ini adalah pemilihan profesi sebagai Akuntan Publik yaitu minat menjadi praktisi individual atau anggota Kantor Akuntan Publik yang memberikan jasa auditing professional kepada klien. Minat menjadi Akuntan Publik diukur dengan professi Akuntan Publik dapat memperluas wawasan dan kemampuan akuntansi, Akuntan Publik dapat menjanjikan lebih professional dalam bidang akuntansi, Imbalan yang diperoleh sesuai dengan upaya yang diberikan, keamanan kerja lebih terjamin dan memperoleh penghargaan yang tinggi di masyarakat.

Alat yang dipakai untuk menghimpun data dalam penelitian ini adalah daftar pernyataan yang sering disebut secara umum dengan nama kuesioner. Data yang diharapkan untuk penelitian ini bersumber dari kepustakaan dan lapangan. Data kepustakaan merupakan data yang lebih dimanfaatkan untuk mengidentifikasi indikator faktor-faktor yang mempengaruhi pemilihan karir sebagai akuntan publik. Data primer diperoleh dari penelitian lapangan, yaitu berasal dari jawaban kuesioner yang termasuk dalam sampel penelitian.

Pengukuran variabel dependen dan independen menggunakan skala likert, yaitu: 'Sangat Setuju' (SS), 'Setuju' (S), 'Kurang Setuju' (KS), 'Tidak Setuju' (TS), 'Sangat Tidak Setuju' (STS). Dari kelima pilihan jawaban tersebut, masing-masing diberi nilai 5 untuk 'Sangat Setuju' (SS), nilai 4 untuk 'Setuju' (S), nilai 3 untuk 'Kurang Setuju' (KS), nilai 2 untuk 'Tidak Setuju' (TS), nilai 1 untuk 'Sangat Tidak Setuju' (STS).

Metode yang digunakan dalam penelitian lapangan adalah survey langsung ke lapangan. Dalam metode ini peneliti mendatangi secara langsung responden untuk pengisian kuesioner, dengan cara penulis membagikan sendiri kepada setiap responden. Setiap responden diberi waktu satu sampai tiga minggu. Metode ini dipilih karena lokasi responden tersebar, sehingga dengan metode ini diharapkan dapat menghe-mat biaya dan waktu.

Instrumen penelitian diuji dengan menggunakan uji validitas dan reliabilitas. Uji validitas instrument dilakukan dengan metode confirmatory factor analysis, hasilnya 1 item pertanyaan dalam instrumen tidak digunakan dalam analisis. Uji reliabilitas dilihat melalui nilai cronbach alpha, hasilnya nilai standardized item cronbach's alpha untuk variabel dependen sebesar 0,641 sehingga pengujian reliabilitas dalam penelitian ini dapat diterima.

Alat analisis yang digunakan untuk melihat pengaruh biaya USAP, proses USAP, resiko pekerjaan terhadap pemilihan karir sebagai akuntan publik oleh akuntan beregister adalah analisis regresi berganda (multiple regression), yang diformulasikan dengan persamaan sebagai berikut:

$$
\mathbf{Y}=\mathbf{a}+\mathbf{b}_{1} \mathbf{X}_{1}+\mathbf{b}_{2} \mathbf{X}_{2}+\mathbf{b}_{3} \mathbf{X}_{3}+\mathbf{e}
$$

Keterangan:

Y : Berprofesi sebagai Akuntan Publik.

a : Konstanta.

b : Koefisien Regresi.

$\mathrm{X}_{1}$ : Biaya USAP. 
$\mathrm{X}_{2}$ : Proses USAP.

$\mathrm{X}_{3}$ : Resiko pekerjaan.

e : Erorr.

\section{Hasil dan Pembahasan}

Hasil analisis dari penelitian ini setelah dilakukan analisis secara kuantitatif dapat di deskripsikan sebagai berikut:

Tabel 1. Statistik Deskriptif Variabel Penelitian.

\begin{tabular}{lccc}
\hline \multicolumn{1}{c}{ Variabel } & N & Mean & Standar Deviasi \\
\hline PKAP & 45 & 8,93 & 1,48 \\
Biaya USAP & 45 & 11,49 & 3,27 \\
Proses USAP & 45 & 11,56 & 2,47 \\
Resiko Pekerjaan & 45 & 12,44 & 1,91
\end{tabular}

Sumber: Hasil Olah Data Statistik Deskriptif, 2013.

Berdasarkan Tabel 1. di atas, dapat dijelaskan beberapa hal berikut: rata-rata Pemilihan Karir Akuntan Publik (PKAP) sebesar 8,93 persen dan standar deviasi sebesar 1,48 persen dengan jumlah observasi (n) sebesar 45. Rata-rata Biaya USAP sebesar 11,49 persen dan standar deviasi sebesar 3,27 persen dengan jumlah observasi (n) sebesar 45 . Rata-rata Proses USAP sebesar 11,56 persen dan standar deviasi sebesar 2,47 dengan jumlah observasi (n) sebesar 45. Rata-rata Resiko Pekerjaan sebesar 12,44 dan standar deviasi sebesar 1,91 dengan jumlah observasi (n) sebesar 45 .

\section{Hasil Analisis Regresi Linier Berganda}

Analisis dalam penelitian ini menggunakan analisis regresi linier berganda. Analisis ini digunakan untuk mengetahui pengaruh dari variabel Biaya Usap, Proses Usap, Resiko Pekerjaan terhadap Pemilihan Karir sebagai Akuntan Publik (PKAP). Berdasarkan hasil perhitungan dengan menggunakan program statistik komputer SPSS for Windows Release 16.00 diperoleh hasil sebagai berikut:

Tabel 2. Hasil Regresi Linier Berganda Metode OLS.

\begin{tabular}{|c|c|c|c|c|c|}
\hline Variabel & & $\begin{array}{c}\text { Koefisien } \\
\text { Regresi }\end{array}$ & $\begin{array}{c}\text { Standart } \\
\text { Error }\end{array}$ & t-statistik & Probabilitas \\
\hline Konstanta & & 16,756 & 1,431 & 11,711 & $0,000 * * *$ \\
\hline Biaya Usap (X1) & & 0,028 & 0,047 & 0,596 & 0,555 \\
\hline Proses Usap (X2) & & $-0,191$ & 0,06 & $-3,161$ & $0,003 * *$ \\
\hline Resiko Pekerjaan (X3) & & $-0,477$ & 0,081 & $-5,917$ & $0,000 * * *$ \\
\hline \multicolumn{6}{|c|}{$R$ square $\quad: \quad 0,631$} \\
\hline Adjusted R square & \multicolumn{5}{|c|}{$: \quad 0,604$} \\
\hline F-statistik & \multicolumn{5}{|c|}{$: \quad 23,390$} \\
\hline Sig. & \multicolumn{5}{|c|}{$: \quad 0,000 * * *$} \\
\hline
\end{tabular}

Sumber: Hasil Olah Data Regresi Linier Berganda, 2013.

$* * *=$ Signifikan $1 \%=<0,001$.

$* * *=$ Signifikan 5\% $=<0,005$. 
Berdasarkan tabel 2 di atas, hasil linier berganda metode OLS dapat dijelaskan bahwa nilai probabilitas t-hitung*** < Level of Significant. Hal ini dapat diartikan bahwa Proses Usap dan Resiko Pekerjaan berpengaruh terhadap Pemilihan Karir sebagai Akuntan Publik (PKAP), sedangkan Biaya Usap berpengaruh, tetapi tidak signifikan terhadap PKAP. Pada pengujian pengaruh secara bersama-sama nilai probabilitas $\mathrm{F}$ hitung*** < Level of Significant. Hal ini dapat diartikan Biaya Usap , Proses Usap dan Resiko Pekerjaan berpengaruh secara bersamasama terhadap PKAP. Nilai $\mathrm{R}^{2}$ (Koefisien Determinasi) sebesar 0,631 artinya variabel dependen (Y) dalam model yaitu PKAP dijelaskan oleh variabel independen yaitu Biaya Usap, Proses Usap dan Resiko Pekerjaan sebesar 36,9 persen, sedangkan sisanya sebesar 63,1 persen dijelaskan oleh faktor lain di dalam model.

\section{Hasil Pengujian Hipotesis}

\section{Hasil Uji-t}

Uji t digunakan untuk membuktikan pengaruh Biaya Usap, Proses Usap dan Resiko Pekerjaan terhadap PKAP secara individual dengan asumsi bahwa variabel yang lain tetap atau konstan. Berdasarkan hasil perhitungan dengan menggunakan program statistik komputer SPSS for Windows Release 16.00 diperoleh hasil sebagai berikut:

\section{Pengujian Pengaruh Variabel Biaya USAP $\left(X_{1}\right)$ terhadap PKAP $(Y)$.}

Dengan taraf nyata $(\alpha)=5 \%=0,05$, pengujian satu sisi dengan derajat kebebasan (degree of freedom) yaitu: $\mathrm{df}=(\mathrm{n}-\mathrm{k})=45-$ $4=41$, diperoleh $t_{\text {tabel }}=1,684$ dan dari hasil regresi berganda diperoleh $\mathrm{t}_{\text {-statistik }}=0,596$.

Tabel 3. Hasil Uji t Variabel Biaya USAP.

\begin{tabular}{ccccc}
\hline Variabel & $\mathbf{t}_{\text {-statistik }}$ & $\mathbf{t}_{\text {-tabel }}$ & Sig. & Keterangan \\
\hline Biaya Usap & 0,596 & 1,684 & 0,555 & Tidak Signifikan \\
\hline
\end{tabular}

Sumber: Hasil Olah Data Regresi Linier Berganda, 2013.

Berdasarkan tabel 4. di atas, diperoleh nilai probabilitas $\mathrm{t}_{\text {-statistik }}=0,555>$ Level of Significant $=0,05$, maka disimpulkan bahwa terdapat pengaruh positif, tetapi tidak signifikan antara Biaya Usap $\left(\mathrm{X}_{1}\right)$ terhadap PKAP (Y). hal ini dapat diartikan jika Biaya Usap mengalami peningkatan, maka Pemilihan Karir sebagai Akuntan Publik juga akan mengalami peningkatan akan tetapi peningkatannya tidak signifikan.

Dengan demikian hal ini bertentangan dengan $\mathrm{H}_{1}$ yang menyatakan bahwa Biaya Usap berpengaruh signifikan terhadap Pemilihan Karir sebagai Akuntan Publik, oleh karena itu maka $\mathrm{H}_{1}$ ditolak. Hasil penelitian ini tidak seseuai dengan pernyataan yang disampaikan Dewan Kehormatan Ikatan Akuntan Indonesia - Sukrisno Agoes dalam artikel yang ditulis Nugroho Cahyo (2011).

\section{Pengujian Pengaruh Variabel Proses USAP $\left(\mathrm{X}_{2}\right)$ terhadap PKAP $(\mathrm{Y})$.}

Dengan taraf nyata $(\alpha)=5 \%=0,05$, pengujian satu sisi dengan derajat kebebasan (degree of freedom) yaitu: $\mathrm{df}=(\mathrm{n}-\mathrm{k})=45-4$ $=41$, diperoleh $\mathrm{t}_{\text {-tabel }}=-1,684$ dan dari hasil regresi berganda diperoleh $\mathrm{t}_{\text {-statistik }}=-3,161$.

Tabel 4. Hasil Uji t Variabel Proses USAP.

\begin{tabular}{ccccc}
\hline Variabel & $\mathbf{t}_{\text {-statistik }}$ & $\mathbf{t}_{\text {-tabel }}$ & Sig. & Keterangan \\
\hline Proses Usap & $-3,161$ & $-1,684$ & 0,003 & Signifikan
\end{tabular}

Sumber: Hasil Olah Data Regresi Linier Berganda, 2013. 
Berdasarkan tabel 5. di atas, diperoleh nilai probabilitas $\mathrm{t}_{\text {-statistik }}=0,003<$ Level of Significant $=0,05$, maka disimpulkan bahwa terdapat pengaruh negatif dan signifikan antara Proses Usap $\left(\mathrm{X}_{2}\right)$ terhadap PKAP $(\mathrm{Y})$. hal ini dapat diartikan jika Proses Usap mengalami semakin mudah, maka Pemilihan Karir sebagai Akuntan Publik juga akan mengalami peningkatan yang signifikan. Dengan demikian hal ini sesuai dengan $\mathrm{H}_{2}$ yang menyatakan bahwa Proses Usap berpengaruh signifikan terhadap Pemilihan Karir sebagai Akuntan Publik, oleh karena itu maka $\mathrm{H}_{2}$ diterima.

\section{Pengujian Pengaruh Variabel Resiko Pekerjaan $\left(\mathrm{X}_{3}\right)$ terhadap PKAP $(\mathrm{Y})$.}

Dengan taraf nyata $(\alpha)=5 \%=0,05$, pengujian satu sisi dengan derajat kebebasan (degree of freedom) yaitu: $\mathrm{df}=(\mathrm{n}-\mathrm{k})=45-4$ $=41$, diperoleh $\mathrm{t}_{\text {-tabel }}=-1,684$ dan dari hasil regresi berganda diperoleh $\mathrm{t}_{\text {-statistik }}=-5,917$.

Tabel 5. Hasil Uji t Variabel Resiko Pekerjaan.

\begin{tabular}{ccccc}
\hline Variabel & $\mathbf{t}_{\text {-statistik }}$ & $\mathbf{t}_{\text {-tabel }}$ & Sig. & Keterangan \\
\hline Resiko Pekerjaan & $-5,917$ & $-1,684$ & 0,000 & Signifikan \\
\hline
\end{tabular}

Sumber: Hasil Olah Data Regresi Linier Berganda, 2013.

Berdasarkan tabel 6. di atas, diperoleh nilai probabilitas $\mathrm{t}_{\text {-statistik }}=0,000<$ Level of Significant $=0,05$, maka disimpulkan bahwa terdapat pengaruh negatif dan signifikan antara Resiko Pekerjaan $\left(\mathrm{X}_{3}\right)$ terhadap PKAP (Y). Hal ini dapat diartikan jika Resiko Pekerjaan sebagai akuntan publik semakin rendah, maka Pemilihan Karir sebagai Akuntan Publik juga akan mengalami peningkatan yang signifikan. Dengan demikian hal ini sesuai dengan $\mathrm{H}_{3}$ yang menyatakan bahwa Resiko Pekerjaan berpengaruh signifikan terhadap Pemilihan Karir sebagai Akuntan Publik, oleh karena itu maka $\mathrm{H}_{3}$ diterima.

\section{Hasil Uji F}

Dengan taraf nyata $(\alpha)=5 \%=0,05$, pengujian satu sisi dengan derajat kebebasan (degree of freedom) yaitu: $\mathrm{df} 1=3 \mathrm{dan} \mathrm{df} 2=$ 41, maka diperoleh $\mathrm{F}_{\text {-tabel }}=8,59$ dan dari hasil regresi berganda diperoleh $\mathrm{F}_{\text {-statistik }}=$ 23,390 .

Tabel 6. Hasil Uji F.

\begin{tabular}{cccc}
\hline $\mathbf{F}_{\text {-statistik }}$ & $\mathbf{F}_{\text {-tabel }}$ & Sig. & Keterangan \\
\hline 23,390 & 8,59 & 0,000 & Signifikan \\
\hline
\end{tabular}

Sumber: Hasil Olah Data Regresi Linier Berganda, 2013.

Berdasarkan tabel 7. di atas, diperoleh Fstatistik $(23,390)>$ Ftabel $(8,59)$ dan nilai probabilitas F-hitung*** < Level of Significant, maka dapat diartikan Biaya Usap, Proses Usap dan Resiko Pekerjaan berpengaruh signifikan secara bersama-sama terhadap PKAP. Dengan demikian hal ini sesuai dengan $\mathrm{H}_{4}$ yang menyatakan bahwa Biaya USAP, Proses USAP, dan Resiko Pekerjaan secara bersama-sama berpengaruh signifikan terhadap Pemilihan Karir sebagai Akuntan Publik, oleh karena itu maka $\mathrm{H}_{4}$ diterima.

\section{Kesimpulan}

Berdasarkan hasil analisis di atas dapat disimpulkan bahwa:

1. Biaya USAP terbukti berpengaruh terhadap pemilihan karir sebagai akuntan publik akan tetapi pengaruhnya tidak 
signifikan.

2. Proses USAP terbukti mempengaruhi akuntan beregister untuk memilih karir sebagai akuntan publik secara signifikan.

3. Resiko pekerjaan sebagai akuntan publik terbukti mempengaruhi akuntan beregister untuk memilih karir sebagai akuntan publik secara signifikan.

4. Biaya USAP, proses USAP dan resiko pe-kerjaan secara bersama-sama terbukti mempengaruhi akuntan beregister untuk memilih karis sebagai akuntan publik secara signifikan.

\section{Saran}

Adapun saran yang dapat diajukan dari penelitian yang telah dilakukan antara lain sebagai berikut:

1. Proses USAP yang diselenggarakan oleh Ikatan Akuntan Publik Indonesia (IAPI) diharapkan dapat ditinjau kembali agar proses untuk mendapatkan CPA lebih singkat dan tidak memberlakukan sistem gugur untuk modul yang sudah lulus.

2. Penelitian ini hanya menganalisis tiga faktor yang mempengaruhi pemilihan karir sebagai akuntan publik, oleh karena itu bagi peneliti selanjutnya disarankan untuk menggunakan lebih banyak faktor seperti penghargaan finansial, pengakuan professional, nilai-nilai sosial dan personalitas untuk memperkaya hasil penelitian dan menghasilkan data yang lebih akurat.

3. Hasil penelitian ini diharapkan dapat dijadikan sebagai acuan bagi peneliti lain untuk mengembangkan maupun mengoreksi dan melakukan perbaikan seperlunya.

\section{Daftar Pustaka}

Andriati, Hastutie N. (2001). "Perilaku Mahasiswa Akuntansi dan Faktor-faktor yang Mempengaruhi Pemilihan Karir Sebagai Akuntan Publik". Tesis Magister Sains UGM Yogyakarta, Unpublished.

Dewan Sertifikasi Institut Akuntan Publik Indonesia, Buletin Informasi Ujian
Indonesia Certified Public Accountant. IAPI. 2012.

Gomes, Faustino Cardoso. 2000. Manajemen Sumber Daya Manusia. Jakarta: Andi Offset.

Hasibuan, Malayu S. P. (2003). Manajemen Sumber Daya Manusia. Edisi Revisi. Cetakan Keenam. Jakarta: PT. Bumi Aksara.

Indrianto, Nur, dan Bambang, Supomo. 2000. Metodologi Penelitian Bisnis untuk Akuntansi \& Manajemen Yogyakarta: BPFE.

Lara Absara Aprilyan. 2011. Faktor-Faktor yang Mempengaruhi Mahasiswa Akuntansi dalam Pemilihan Karir Menjadi Akuntan Publik. Skripsi. Published. Semarang: Undip.

Lind, Marchal, Wathen. 2005. Statistical Techniques in Business \& Economics. Mc Graw Hill, twelfth edition.

Mangkunegara, Anwar Prabu. 2007. Evaluasi Kinerja SDM. Cetakan Ketiga. Bandung: PT. Refika Aditama.

Mulyadi. 2002. Auditing. Edisi Keenam. Buku Dua. Jakarta: Salemba Empat.

Cahyo, Nugroho. 2011. Fresh Graduate Kurang Berminat Menjadi Akuntan Publik. Artikel.

2011. Pengaruh Motivasi Diri dan Pengetahuan tentang Profesi akuntan Publik terhadap Minat untuk Berprofesi sebagai Akuntan Publik pada Mahasiswa Program Studi Akuntansi UNY. Skripsi. Yogyakarta: Universitas Negeri Yogyakarta.

Cooper, Donald R. \& Schindler, Pamela S. (2006). Business Research Method. Mc Graw Hill, ninth edition. 
Rahayu, Sri dkk. (2003). Persepsi Mahasiswa Mengenai Faktor-Faktor yang Mempengaruhi Pemilihan Karir. Simposium Nasional Akuntansi IV. 16-17 Oktober 2003. Surabaya.

Rivai, Vethzal. 2006. Manajemen Sumber Daya Manusia untuk Perusahaan: Dari Teori ke Praktek. Edisi Pertama. Jakarta: PT. Raja Grafindo Persada.

Robbins, S.P. (2001). Psikologi Organisasi. Edisi ke-8. Jakarta: Prenhallindo.

Rasmini, Ni Ketut. 2007. Faktor-Faktor yang Berpengaruh pada Keputusan Pemilihan Profesi Akuntan Publik dan Non Akuntan Publik pada Mahasiswa Akuntansi di Bali. Buletin Studi Ekonomi Volume 12 Nomor 3 Tahun 2007. Bali: Fakultas Ekonomi Universitas Udayana.

Simamora, Henry. 2004. Manajemen Sum- ber Daya Manusia. Edisi Pertama. Cetakan Kelimabelas. Jakarta: PT. Bumi Aksara.

Sofyandi, Garniwa. 2007. Perilaku organisasi. Yogjakarta: Graha Ilmu.

Sugiyono. 2005. Metode Penelitian Administratif. Edisi ke-12. Jakarta: CV. Alfabeta.

Walgito, Bimo. 2000. Pengantar Psikologi Umum. Yogyakarta: Andi Offset.

Wijayanti. 2003. Faktor-Faktor yang Mempengaruhi Pemilihan Karir Mahasiswa Akuntansi di Yogyakarta. Jurnal Riset Akuntansi Indonesia. Vol. 3 No. 2.

Media Akuntansi, 28 September 2002.

PPAJP Kementrian Keuangan Republik Indonesia. 2012. 


\section{AKMENIKA}

\section{KETENTUAN PENULISAN NASKAH JURNAL}

Artikel yang ditulis untuk dimuat dalam Jurnal Akuntansi dan Manajemen adalah hasil penelitian dalam bidang Akuntansi dan Manajemen. Artikel diketik dengan huruf Time New Roman, ukuran 12 pts, spasi ganda, dicetak di atas kertas HVS ukuran kuarto, sebanyak 25 halaman dan diserahkan dalam bentuk print out 2 eksemplar beserta soft copy. Pengiriman soft copy juga dapat dilakukan melalui e-mail ke alamat : akmenikaupy@gmail.com.

1. Nama penulis ditulis tanpa gelar akademik dengan nama, alamat lembaga, dan alamat e-mail. Jika penulis terdiri dari dua orang atau lebih, alamat e-mail hanya untuk penulis pertama.

2. Artikel ditulis dalam Bahasa Indonesia atau bahasa Inggris dengan format esai. Judul artikel diketik dengan huruf kapital, ukuran 14 pts, tercetak tebal (bolt), dengan posisi center.

3. Bila penulis mencantumkan tabel, maka garis yang tercetak pada tabel hanya garis mendatar batas atas, garis mendatar batas judul kolom dengan isi tabel, dan garis mendatar batas bawah. Bila baris terakhir isi tabel berupa penjumlahan bilangan, maka di samping garis mendatar batas bawah juga perlu garis mendatar batas penjumlahan bilangan tersebut. Nomor dan judul tabel tertulis di atas tabel dengan bernomor urut mulai tabel 1 dan seterusnya. Contoh: Tabel 1. Pertumbuhan Ekonomi, Investasi Domestik, dan Ekspor... (Nomor dan Judul Tabel dicetak tebal). Sumber data diletakkan di bawah tabel sebelah kiri.

4. Sistematika artikel adalah sebagai berikut:

- Judul

- Nama Penulis

- Alamat Lembaga

- Alamat e-mail

- Abstract (ditulis dalam bahasa Inggris dan bahasa Indonesia, ditulis dalam satu paragraph, maksimum 200 kata). Abstract berisi tujuan penelitian, metode, alat analisis data, hasil penelitian dan keywords.

- Pendahuluan (tanpa judul) berisi latar belakang, rumusan masalah, tujuan penelitian, manfaat penelitian, kajian teori dan hipotesis

- Metode berisi populasi, sampel, teknik sampling, teknik pengumpulan data, dan teknik analisis data

- Hasil Penelitian dan Pembahasan

- Simpulan

- Daftar Pustaka (hanya memuat sumber-sumber yang dirujuk)

5. Sumber referensi sedapat mungkin hasil tulisan 10 tahun terakhir. Referensi yang diutamakan adalah berupa artikel-artikel hasil penelitian yang ditulis dalam jurnal, majalah ilmiah, internet dan laporan penelitian (termasuk disertasi, tesis, dan skripsi).

6. Perujukan dan pengutipan pendapat atau definisi menggunakan teknik rujukan berkurung (nama, tahun: halaman). Contoh: Ekuitas merk adalah... (Kotler dan 
Keller, 2012:25) atau Menurut Kotler dan Keller (2012:25) ekuitas merk adalah..... Penulisan sumber pada kutipan tak langsung menggunakan kata "dalam". Contoh: Menurut The American Marketing Association (dalam Kotler dan Amstrong, 2011:35) pemasaran adalah...., .....Perujukan dari hasil penelitian tidak perlu menunjuk halaman. Contoh: menurut penelitian Chandra (2010) citra merk berpengaruh terhadap kepuasan konsumen,....

7. Daftar Pustaka disusun secara Alfabetis

Buku:

Ross, Stephen A, Randolph W. Westerfiled, Jeffrey, Jaffe \& Bradford D. Jordan. 2008. Modern of Financial Management. Eighth Edition. New York: McGraw-Hill Irwin.

Buku Kumpulan Artikel:

Saukah, A. \& M.G. Waseso (Eds.). 2002. Menulis Artikel untuk Jurnal Ilmiah (edisi ke-4, cetakan ke-1), Malang: UM Press.

Artikel dalam Buku Kumpulan Artikel:

Butler, Timothy \& James Waldrood. 1999. Seni Merancang pekerjaan. Dalam Dewi, Ike Janita (Ed.), Maximum Motivation: Konsep \& Implikasi Manajerial dalam Memotivasi Karyawan (hlm. 99-123). Yogyakarta: Penerbit Santusta.

\section{Artikel dalam Jurnal atau Majalah:}

Pettigrew, Andrew M, Richard W. Woodman \& Kims Cameron. 2001. "Studying Organizational Change and Development: Challengers for Future research". The Academic of Management Journal, Vol.44 (august): 679-750.

\section{Artikel dalam Surat Kabar:}

Prasetyantoko, A. 20 Oktober 2008. Kembalinya Pendulum Perdagangan. Kompas, hlm.6.

Tulisan/berita dalam Surat Kabar (tanpa nama pengarang):

Kompas, 28 Maret 2009. Ekonomi Melambat; Ekspor sudah Merosot 30 Persen, hlm.4.

\section{Dokumen Resmi:}

Pusat Pembinaan dan pengembangan Bahasa. 1978. Pedoman Penulisan Laporan Penelitian. Jakarta: Depdikbud.

\section{Buku Terjemahan:}

Kotler, Philips \& Gary amstrong. 2008. Prinsip-prinsip Pemasaran. Edisi 12. Jilid 1. Terjemahan oleh Bob Sabran 2008. Jakarta: Erlangga.

\section{Skripsi, Tesis, Disertasi, Laporan Penelitian:}

Putri, Melania Intan. 2009. Analisis Pengaruh kualitas Jasa perawatan Kecantikan terhadap Kepuasan dan Loyalitas pelanggan: Studi Kasus pada Pelanggan 
Klinik Perawatan kecantikan Larissa Skin Care \& Hair Treatment Yogyakarta. Skripsi tidak dipublikasikan. Yogyakarta: FE USD.

Makalah Seminar, Lokakarya, Penataran:

Saptaningsih S., Lilik W. 2012. Peningkatan Daya Saing Yogyakarta dari Perspektif Kepariwisataan dan Ekonomi: dari Masa ke Masa. Makalah disajikan pada Seminar Ilmiah dengan Tema "meningkatkan Daya Saing Yogyakarta" dalam rangka Dies Natalis ke-30 Universitas PGRI Yogyakarta, Yogyakarta, 20 Desember 2012.

\section{Internet (artikel dalam jurnal online):}

Wuri, Josephine. 2006. “Lembaga Penjamin Simpanan: Strategi Mengatasi Bank Rush" Jurnal Akuntansi dan manajemen: Antisipasi. (online), Vol.5, No. 1, (http://www.ekonomi.upy.ac.id, diakses 20 januari 2013).

8. Nomor dan judul gambar/bagan/grafik selanjutnya disebut gambar, ditulis di bawah gambar dengan posisi center. Sumber data di tulis di bawah gambar sebelah kiri.

9. Nomor dan judul Tabel ditulis di atas Tabel dengan posisi center. Sumber data ditulis di bawah table sebelah kiri.

10. Semua naskah ditelaah secara anonym (blind review) oleh mitra bebestari yang ditunjuk oleh penyunting menurut kepakarannya. Penulis artikel diberi kesempatan untuk memperbaiki naskahnya, jika naskah artikel layak dimuat tetapi masih perlu direvisi atas dasar saran dari mitra bebestari atau penyunting jurnal. Kepastian pemuatan atau penolakan naskah akan diberitahukan secara tertulis.

11. Naskah artikel yang sudah dicetak dalam bentuk cetak coba, dapat dibatalkan pemuatannya oleh penyunting jika diketahui bermasalah.

12. Naskah artikel yang tidak dimuat di jurnal tidak dikembalikan ke penulis, kecuali ada permintaan dari penulis.

13. Segala sesuatu yang menyangkut masalah perijinan, pengutipan atau penggunaan software computer untuk pembuatan naskah, pengolahan data dan hal lain yang terkait dengan HAKI yang dilakukan oleh penulis artikel, berikut konsekuensi hukum yang mungkin timbul, sepenuhnya menjadi tanggungjawab penulis artikel. 